\title{
Pengaruh Nilai Plasticity Index Material Plastis terhadap California Bearing Ratio Lapis Pondasi Agregat Kelas-S
}

\author{
${ }^{1}$ Dj P Marpaung, ${ }^{2}$ Elvira Handayani, ${ }^{3}$ Irwan Hely Muhnandar \\ ${ }^{1,2}$ Dosen Fakultas Teknik Sipil Universitas Batanghari Jambi \\ ${ }^{3}$ Mahasiswa Teknik Sipil Universitas Batanghari Jambi \\ Email : elvira.handayani2@yahoo.co.id
}

\begin{abstract}
Abstrak
Penelitian ini bertujuan untuk melihat Pengaruh Nilai Plasticity Index Material Plastis Terhadap spesifikasi Lapis Pondasi Agregat Kelas-S sebagaimana diatur dalam Spesifikasi Umum Binamarga 2010 (revisi 3). Penelitian dilakukan di Laboratorium Fakultas Teknik Universitas Batanghari dan sampel material yang digunakan dalam penelitian ini adalah Sirtu, Batu Pecah 1-2 dan Tanah.Sampel Sirtu diambil di daerahdi Pal 10 Kota Jambi, Batu pecah 1-2 ex. Concrete batching plant Citra Beton, dan tanah di Desa Sungai Benteng Sarolangun. Komposisi campuran Sirtu: Batupecah: Tanah untuk benda uji dibuat sebanyak tiga variasi. Komposisi 1 (65\%:15\%:20\%), komposisi 2 (60\%:15\%:25\%) dan komposisi 3 (55\%:15\%:30). Uji CBR yang dilakukan adalah Uji CBR rendaman, Hasil uji menunjukkan sirtu dan batu pecah adalah material nonplastis. Sedangkan tanah memiliki PI (Plasticity Index $=14,50 \%$. Hasil penelitian terhadap komposisi campuran menunjukkan bahwa semakin banyak persentase tanah dalam komposisi akan menyebabkan nilai PI semakin Besar. Semakin besar nilai PI akan menyebabkan semakin rendahnya dilai CBR. Ketiga komposisi campuran masih memenuhi persyaratan spesifikasi umum binamarga 2010 (revisi 3).
\end{abstract}

Kata Kunci : komposisi campuran, Plasticity Index, California Bearing Ratio.

\section{PENDAHULUAN}

Pembangunan dibidang konstruksi yang sering disebut dengan pekerjaan konstruksi berkembang dengan pesat. Pesatnya perkembangan dan pembangunan di Indonesia tidak terlepas dari kemajuan suatu daerah. Di Jambi khususnya hal tersebut dapat dilihat dengan adanya proyek-proyek pembangunan, jalan, gedung, jembatan, perhotelan, bendungan, saluran irigasi kota, instalasi pengolahan limbah atau air bersih yang dilaksanakan baik oleh dinas pemerintah maupun swasta.

Konstruksi jalan umumnya terdiri dari lapis perkerasan dari berbagai macam agregat dan campuran bahan material seperti pasir, kerikil, batu pecah dan tanah yang biasanya memiliki sifat plastisitas sehingga akan mempengaruhi konstruksi jalan tersebut. Salah satu fungsi lapis pondasi adalah menopang lapis permukaan dan beban roda kendaraan. Oleh karena itu material yang digunakan sebagai lapis pondasi harus memenuhi spesifikasi yang ada.

Menurut Spesifikasi Umum Bina Marga 2010 (Revisi3) pada Lapis Pondasi Agregat Kelas-S harus memiliki persyaratan nilai PI (Plasticity Index) minimal 4\% dan maksimal $15 \%$ dan harus mencapai nilai CBR minimal 50\%. Adanya persyaratan nilai PI (Plasticity Index) yang $\geq 4 \%$ mengisyaratkan bahwa memerlukan bahan campuran untuk material yang bersifat plastis yaitu dengan tanah yang mengandung lempung (clay) berfungsi untuk mengikat material sehingga persyaratan nilai PI (Plasticity Index) terpenuhi. Dengan dilatarbelakangi permasalahandiatas, maka dilakukan penelitian di Laboratorium Fakultas Teknik Universitas Batangharimengenaipengaruhnilai PI terhadapnilai CBR Lapis PondasiKelas-S.

Sejarah perkerasan jalan dimulai bersamaan dengan sejarah umat manusia itu sendiri yang selalu berhasrat untuk mencari kebutuhan hidup dan berkomunikasi dengan sesama. Dengan demikian perkembangan jalan saling berkaitan dengan perkembangan umat manusia. Perkembangan teknik jalan seiringan dengan perkembangan teknologi yang ditemukan umat manusia. Konstruksi perkerasan lentur (Flexible Pavement)Konstruksi perkerasan kaku 
(Rigid Pavement),Konstruksi perkerasan komposit (Composite Pavement)Lapisan Permukaan (Surface Course)Lapisan Pondasi Atas (Base Course)Lapisan Pondasi Bawah (Subbase Course)Lapisan Tanah Tasar (Subgrade)Lapis Pondasi Agregat Kelas S berfungsi sebagai lapis perkerasan bahu jalan dan disyaratkan harus memiliki nilai plastisitas yang berkisar antara 4\% sampai 15\% nilai Abarasi dari agregat kasar antara 0\% sampai $40 \%$ nilai butiran pecah tertahan ayakan $3 / 8 " 55 / 50^{2}$ ) (mempunyai satu bidang pecah atau lebih dan dua bidang pecah atau lebih) batas cair 0 sampai $35 \%$ banyaknya pukulan atau ketukan, gumpalan lempung dan butiran-butiran mudah pecah 0\% sampai 5\% dan nilai California Bearing Ratio (CBR) minimal 50\% (Spesifikasi umum bina marga 2010 Revisi 3).

Menurut Suyono Sosrodarsono (1984) tanah didefinisikan sebagai partikel-partikel mineral yang tersemen maupun yang lepas sebagai hasil pelapukan dari batuan, dimana rongga pori antar partikel terisi oleh udara dan atau air. Akibat pengaruh cuaca dan pengaruh lainya, tanah mengalami pelapukan sehingga terjadi perubahan ukuran dan bentuk butirannya. Pelapukan batuan dapat disebabkan oleh pelapukan mekanis, kimia dan organis.

1. Sistem Klasifikasi Tanah Berdasarkan Unified Soil Classification System (USCS)

2. Sistem Klasifikasi AASHTO (The American Association of State Highway and Transportation Officials)

Agregat atau batuan merupakam komponen utama dari lapis perkerasan jalan yang mengandung 90 - 50\% agregat berdasarkan persentase berat atau 75 - 85\% agregat berdasarkan persentase berat volume. Dengan demikian daya dukung, keawetan dan mutu perkerasan jalan ditentukan juga dari sifat agregat dan hasil campuran agregat dengan material lain.(Silvia Sukirman, 1992).

Atterberg (1911), memberikan cara untuk menggambarkan batas-batas konsistensi dari tanah berbutir halus dengan mempertimbangkan kandungan kadar air tanah. Batas-batas tersebut adalah batas cair (liquid limit), batas plastis (plastic limit), dan batas susut (Shrinkage limit).

Pemadatan merupakan usaha untuk mempertinggi kerapatan tanah dengan pemakaian energi mekanis untuk menghasilkan pemampatan partikel. Tanah dapat dikerjakan pada mulanya dengan pengeringan, penambahan air, agregat (butir-butir) atau dengan bahan-bahan stabilisasi seperti semen, gamping, abu batu bara atau bahan lainya (Joseph E. Bowls, 1989)

CBR adalah perbandingn antara beban yang dibutuhkan untuk penetrasi contoh tanah sebesar $0,1 " / 0,2 \%$. CBR merupakan suatu perbandingan antara beban percobaan (test load)dengan beban standar dan dinyatakan dalam persen. Harga CBR adalah salah satu parameter yang digunakan untuk mengetahui kuat dukung tanah dasar dalam perencanaan lapis perkerasan.

\section{METODE PENELITIAN}

Untuk mencapai tujuan dari penelitian ini langkah yang harus dilaksanakan adalah mengawali dengan memilih agregat dan tanah yang akan digunakan dimana pengambilan material sirtu bersumber dari Pal 10 Kota Jambi dan material tanah dari Desa Sungai Benteng. Material tersebut kemudian dilakukan pemeriksaan terhadap sifat-fisik material. Pemeriksaan fisik material meliputi analisa saringan, pengujian berat jenis agregat kasar, pengujian gumpalan lempung dan butiran-butiran mudah pecah dalam agregat, pemeriksaan abrasi dengan mesin Los Angeles, berat jenis dan peresapan agregat halus, pengujian berat isi campuran agregat lapon, dan pengujian konsistensi atterberg. Kemudian dilakukan komposisi campuran penambahan tanah Batu Pecah 1-2 dan sirtu. Pembuatan benda uji dari setiap variasi berdasarkan nilai PI selanjutnya akan dilaksanakan pengujian pemadatan, pemadatan untuk mendapatkan kadar air optimum. Kadar air optimum yang didapat digunakan untuk pengujian CBR laboratorium. Benda uji untuk pengujian CBR (California Bearing Ratio) laboratorium direndam selama 4 hari lalu dilakukan pemeriksaan CBR.Dari 

Kelas-S

hasil pemeriksaan CBR kemudian dianalisa bagaimana pengaruh nilai indeks plastisitas terhadap CBR lapis Pondasi Agregat Kelas-S.

\section{HASIL DAN PEMBAHASAN \\ Sirtu}

Karakter sirtu yang diambil dari Pal 10 kota Jambi yaitu sirtu lokal yang dalam kondisi ini mempunyai gradasi ukuran mulai dari lolos saringan 11/2" sampai lolos no. 200 dari penelitian menunjukkan berat jenis penyerapan $2,47 \%$, mempunyai saringan tertahan no. 4 sebanyak 68,903\% sedangkan yang lolos dari no. 4 sebanyak 31,10\% dan keausan agregat $38,55 \%$ merupakan sirtu yang bisa digunakan dalam bahan perkerasan jalan. Sedangkan hasil pengujian dan penelitian bisa dilihat pada tabel 1

Tabel 1 Hasil Rangkuman Pengujian Sirtu

\begin{tabular}{|c|c|c|c|c|c|}
\hline NO & \multicolumn{2}{|c|}{ JENIS PENGUJIAN } & $\begin{array}{c}\text { UKURAN } \\
\text { SARINGAN }\end{array}$ & $\begin{array}{c}\text { HASIL } \\
\text { TES } \\
\%\end{array}$ & $\begin{array}{c}\text { SPESIFIKASI } \\
\text { LAPIS PONDASI } \\
\text { KELAS S } \\
\text { BINA MARGA } \\
\text { TAHUN 2O1O REVISI } 3\end{array}$ \\
\hline \multirow{8}{*}{1} & \multirow{8}{*}{\multicolumn{2}{|c|}{$\begin{array}{l}\text { ANALISA SARINGAN } \\
\text { ( } \% \text { Lolos Saringan ) }\end{array}$}} & 2" & & \\
\hline & & & $11 / 2 "$ & 100.00 & 100 \\
\hline & & & $1 "$ & 74.91 & $77-89$ \\
\hline & & & $3 / 8$ & 42.82 & $41-66$ \\
\hline & & & $\# 4$ & 31.10 & $26-54$ \\
\hline & & & $\# 10$ & 23.00 & $15-42$ \\
\hline & & & $\# 40$ & 10.15 & $7^{\prime}-26$ \\
\hline & & & $\# 200$ & 5.16 & $4^{\prime}-16$ \\
\hline \multirow{4}{*}{2} & \multirow{4}{*}{ BERAT JENIS KASAR } & \multicolumn{2}{|l|}{ - Berat Jenis Curah } & 2.47 & \multirow{4}{*}{ SNI 1969-2008 } \\
\hline & & \multicolumn{2}{|c|}{ - SSD/jenuh Kering permukaan } & 2.52 & \\
\hline & & \multicolumn{2}{|c|}{ - Semu/ Apparent } & 2.59 & \\
\hline & & \multicolumn{2}{|l|}{ - Absorption (\%) } & 1.81 & \\
\hline \multirow{4}{*}{3} & \multirow{4}{*}{ BERAT JENIS HALUS } & - Berat Jenis Curar & & 2.523 & \multirow{4}{*}{ SNI 1970-2008 } \\
\hline & & \multicolumn{2}{|l|}{ - SSD/JKP } & 2.583 & \\
\hline & & \multicolumn{2}{|l|}{ - Semu/ Apparent } & 2.686 & \\
\hline & & \multicolumn{2}{|l|}{ - Absorption (\%) } & 2.408 & \\
\hline 4 & \multicolumn{3}{|c|}{ GUMPALAN LEMPUNG (\%) } & 0.27 & $0-5 \%$ \\
\hline 5 & \multicolumn{3}{|l|}{ BIDANG PECAH (\%) } & $55 / 50^{21}$ & SNI 7619:2012 \\
\hline 6 & \multicolumn{3}{|c|}{ ABRASI/KEAUSAN AGREGAT (\%) } & 38.55 & $0-40 \%$ \\
\hline \multirow[t]{2}{*}{7} & \multirow{2}{*}{\multicolumn{2}{|c|}{ BERAT ISI AGREGAT (Kg/ltr) }} & LEPAS & 1.665 & \multirow{2}{*}{ SNI O3-4804- 1998} \\
\hline & & & PADAT & 1.782 & \\
\hline
\end{tabular}

Sumber: Data Olahan (2019).

\section{Tanah}

Setelah dilakukan pengamatan terhadap tanah galian yang terletak di Desa Sungai Benteng Sarolangun Contoh tanah yang diambil dengan keadaan terganggu atau disturbed, dengan bentuk bongkahan-bongkahan tanah. Berdasarkan pengamatan visual tanah berwarna kuning kecoklatan-coklatan.

Tanah dalam kondisi ini mempunyai gradasi ukuran mulai dari lolos saringan $3 / 8$ " sampai lolos no. 200 dari penelitian menunjukkan nilai rata-rata berat jenis tanah $2,28 \%$, mempunyai saringan tertahan no. 4 sebanyak 1,5\% sedangkan yang lolos dari no. 4 sebanyak $98,50 \%$ dan untuk tanah $100 \%$ dapat nilai $\mathrm{LL}=28,90 \%, \mathrm{PL}=14,41 \%$ PI $=14,50 \%$, dan kadar air $12,07 \%$. Sedangkan hasil pengujian dan penelitian laboratorium mengenai tanah seperti pada tabel:

Tabel 2 Hasil Rangkuman Pengujian Tanah

\begin{tabular}{|c|c|c|c|c|}
\hline No & JenisPengujian & UkuranSaringan & HasilUji & $\begin{array}{c}\text { Spesifikasi Lapis } \\
\text { PondasiKelas S } \\
\text { BinaMargaTahun } 2010 \\
\text { Revisi 3 }\end{array}$ \\
\hline \multirow{3}{*}{1} & \multirow{3}{*}{$\begin{array}{c}\text { AnalisaSaringan } \\
\text { (\% Lolos Saringan) }\end{array}$} & $2 "$ & & \\
\hline & & $11 / 2^{\prime \prime}$ & 100,00 & 100 \\
\hline & & $1 "$ & 100,00 & $77-89$ \\
\hline
\end{tabular}


Pengaruh Nilai Plasticity Index Material Plastis terhadap California Bearing Ratio Lapis Pondasi Agregat Kelas-S

\begin{tabular}{|c|c|c|c|c|}
\hline & & \multirow[b]{2}{*}{100,00} & \multirow{3}{*}{$41-66$} \\
\hline & & $3 / 8$ & & \\
\hline & & $\# 4$ & 98,50 & \\
\hline & & $\# 10$ & 91,20 & $15-42$ \\
\hline & & $\# 40$ & 55,16 & $7^{\prime}-26$ \\
\hline & & $\# 200$ & 32,76 & $4^{\prime}-16$ \\
\hline \multicolumn{3}{|r|}{ Batas Cair ( LL ) \% } & 28,90 & $0-35$ \\
\hline \multirow[t]{2}{*}{2} & \multirow[t]{2}{*}{ Atterberg Limits } & Batas Plastis ( PL ) \% & 14,41 & - \\
\hline & & IndeksPlastisitas ( PI ) \% & 14,50 & $4-15$ \\
\hline 3 & Kadar Air Tanah (\%) & & 12,07 & SNI 1965-2008 \\
\hline 4 & BeratJenis Tanah (gr/cc) & & 2,28 & SNI 1964-2008 \\
\hline
\end{tabular}

Sember: Data Olahan (2019)

\section{Batu Pecah 1-2}

Batu pecah 1-2 yang berasal dari Stock Pile Beton Ready mix Perusahaan Citra Beton mempunyai ukuran mulai dari lolos saringan 1" sampai lolos no. 200 dari penelitian menunjukan, berat jenis Penyerapan 0,604\% mempunyai saringan tertahan no. 4 sebanyak $98,920 \%$ sedangkan yang lolos dari no. 4 sebanyak 1,08\% dan keausan agregat 38,55\% dan bobot isi lepas $1,665 \mathrm{~kg} / \mathrm{l}$ dan padat $1,782 \mathrm{~kg} / \mathrm{l}$. Hasil pengujian dan penelitian laboratorium seperti pada tabel:

Tabel 3 Hasil Rangkuman Pengujian Batu Pecah 1-2.

\begin{tabular}{|c|c|c|c|c|c|}
\hline No & & ian & UkuranSaringan & HasilTes & $\begin{array}{c}\text { SpesifikasiLapis } \\
\text { PondasiKelas } \\
\text { SBinaMargaTahun } 2010 \\
\text { Revisi } 3\end{array}$ \\
\hline \multirow{8}{*}{1} & \multirow{8}{*}{\multicolumn{2}{|c|}{$\begin{array}{l}\text { AnalisaSaringan } \\
\text { ( \% Lolos Saringan ) }\end{array}$}} & $2 "$ & & \\
\hline & & & $11 / 2 "$ & 100,00 & 100 \\
\hline & & & $1 "$ & 100,00 & $77-89$ \\
\hline & & & $3 / 8$ & 14,12 & $41-66$ \\
\hline & & & $\# 4$ & 1,08 & $26-54$ \\
\hline & & & $\# 10$ & 0,84 & $15-42$ \\
\hline & & & $\# 40$ & 0,81 & $7^{\prime}-26$ \\
\hline & & & \# 200 & 0,73 & $4^{\prime}-16$ \\
\hline \multirow{4}{*}{2} & \multirow{4}{*}{ BeratJenis } & \multirow{4}{*}{\multicolumn{2}{|c|}{$\begin{array}{l}\text { - BeratJenisCurah } \\
\text { - SSD/JenuhPermukaanKering } \\
\text { - Semu/ Apparent } \\
\text { - Absorption }(\%)\end{array}$}} & 2,625 & \multirow{4}{*}{ SNI 1969-2008 } \\
\hline & & & & 2,641 & \\
\hline & & & & 2,668 & \\
\hline & & & & 0,604 & \\
\hline 3 & Abrasi/Keau & & & 38,55 & Maks. 40 \\
\hline \multirow{2}{*}{4} & \multirow{2}{*}{\multicolumn{2}{|c|}{ Berat Isi Agregat }} & Lepas kg/l & 1,665 & \multirow{2}{*}{ SNI 03-4804-1998 } \\
\hline & & & Padat kg/l & 1,782 & \\
\hline
\end{tabular}

Sumber: Data Olahan (2019

\section{Pembahasan}

\section{Campuran Sirtu, Tanah Dan Batu Pecah 1-2}

Pengujian yang dilakukan pada pencampuran sirtu, tanah Batu Pecah 1-2 adalah pengujian berat jenis, batas-batas konsistensi, kepadatan modified CBR rendaman.

\section{a. Berat Jenis}

Pengujian berat jenis dilakukan untuk sirtu batu 1-2 dan tanah berdasarkan persentase masing-masing. hasil pemeriksaan dirangkum dalam tabel 4.4: 
Pengaruh Nilai Plasticity Index Material Plastis terhadap California Bearing Ratio Lapis Pondasi Agregat Kelas-S

Tabel 4 Berat Jenis Gabungan

\begin{tabular}{|c|c|c|c|}
\hline \multicolumn{3}{|c|}{ VARIASI CAMPURAN AGREGAT } & \multirow{2}{*}{ BERAT JENIS GABUNGAN } \\
\hline Sirtu $(\%)$ & Batu 1-2 (\%) & Tanah $(\%)$ & \\
\hline 65 & 15 & 20 & 2,477 \\
\hline 60 & 15 & 25 & 2,465 \\
\hline 55 & 15 & 30 & 2,453 \\
\hline
\end{tabular}

Sumber: Data Olahan (2019)

b. Batas Batas Konsistensi (Atterberg)

Pengujian konsistensi Atterberg dilakukan untuk sirtu dan tanah yang dicampur yang meliputi batas cair dan batas plastis dan untuk mendapatkan nilai index plasticity. Hasil pemeriksaan bisa dilihat pada tabel 5 berikut:

Tabel 5 Nilai Batas Cair, Batas Plastis dan Indeks Plastisitas

\begin{tabular}{lccc}
\hline & \multicolumn{3}{c}{ Nilai } \\
\cline { 2 - 4 } \multicolumn{1}{c}{ VariasiAgregat } & Batas Cair & Batas Plastis & IndeksPlastisitas \\
& $(\mathrm{LL})$ & $(\mathrm{PL})$ & (PI) \\
\hline SirtuAsli & $\%$ & $\%$ & 0 \\
Batu 1-2 Asli & 0 & 0 & 0 \\
Tanah Asli & 0 & 0 & 14,50 \\
Sirtu 65\% + Batupecah 1-2 15\% + Tanah 20\% & 28,90 & 14,41 & 4,16 \\
Sirtu 60\% + Batupecah 1-2 15\% + Tanah 25\% & 27,71 & 23,55 & 6,08 \\
Sirtu 55\% + Batupecah 1-2 15\% + Tanah 30\% & 34,36 & 28,28 & 8,90
\end{tabular}

Sumber: Data Olahan (2019)

Hasil uji menunjukkan bahwa semakin banyak penambahan tanah maka akan semakin besar pula nilai PI. Hasil PI untuk ketiga kombinasi memenuhi Spesifikasi Umum Bina Marga 2010 revisi 3 yaitu antara $4 \%-15 \%$.

\section{c. Percobaan Pemadatan}

Percobaan pemadatan ini dilakukan dengan cara pemadatan modifikasi (Modified Compaction Test) motode D. Pengujianinidilakukan untuk mendapatkan kadar air optimum (Wopt) dan berat isi kering $(\gamma d)$. Hasil pengujian seperti pada tabel 6 berikut ini:

Tabel 6 kadar air optimum (Wopt) dan berat isi kering $(\gamma d)$

\begin{tabular}{cccccc}
\hline \multirow{2}{*}{ No } & & variasi & & $\begin{array}{c}\text { Kadar Air } \\
\text { Optimum (Wopt) }\end{array}$ & $\begin{array}{c}\text { Berat Isi } \\
\text { Kering }(\gamma \mathrm{d})\end{array}$ \\
\cline { 2 - 5 } & Sirtu \% & Batu 1-2\% & Tanah $\%$ & $\%$ & $\left(\mathrm{~g} / \mathrm{cm}^{3}\right)$ \\
\hline 1 & 65 & 15 & 20 & 8,11 & 2,042 \\
2 & 60 & 15 & 25 & 8,60 & 2,011 \\
3 & 55 & 15 & 30 & 8,84 & 2,002 \\
\hline
\end{tabular}

Sumber: Data Olahan (2019)

Dapat disimpulkan bahwa adanya penambahahan agregat plastis membuat Wopt mengalami persentase kenaikan dan untuk $\gamma d$ mengalani Grafik proktor gabungan dari ketiga variasi campuran dibawah ini. 
Pengaruh Nilai Plasticity Index Material Plastis terhadap California Bearing Ratio Lapis Pondasi Agregat Kelas-S

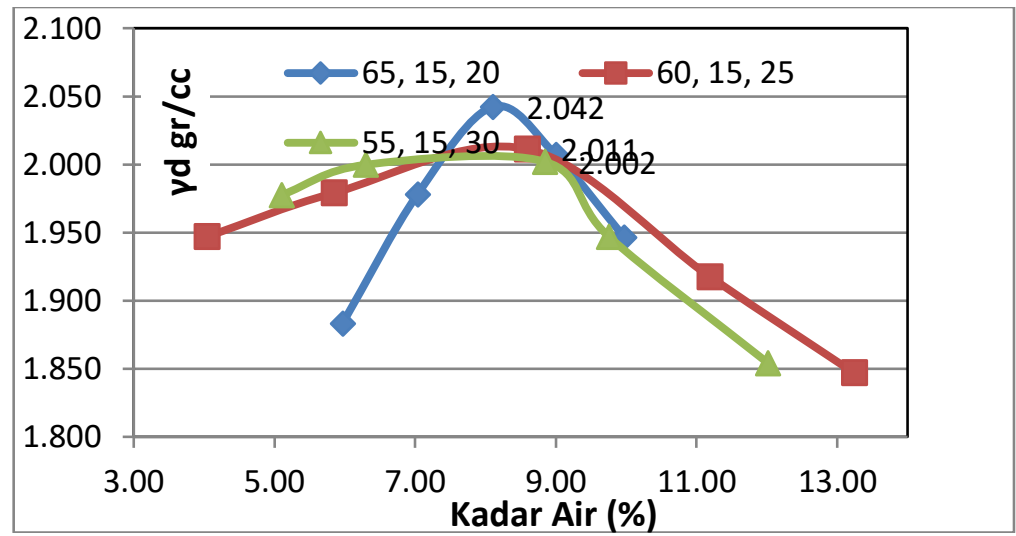

Sumber: Data Olahan (2019)

Gambar 1 Grafik Proktor Gabungan

\section{d. California Bearing Ratio (CBR)}

Pengujian nilai CBR dilakukan untuk penelitian ini adalah dengan kondisi terendam atau $C B R$ soaked. Pengujian ini dilakungan dengan menggunakan mesin penetrasi. Benda uji diperiksa direndam selama 4 hari sebelum melakukan tes . Dari pengujian akan diperoleh nilai CBR pada semua variasi campuran bisa di lihat pada tabel 7 berikut ini:

Tabel 7 Hasil Pengujian CBR Soaked

\begin{tabular}{cccccccc}
\hline \multirow{2}{*}{ No } & \multirow{2}{*}{ VARIASI } & & PI & $\begin{array}{c}\text { Kadar Air } \\
\text { Optimum (Wopt) }\end{array}$ & $\begin{array}{c}\text { Berat Isi } \\
\text { Kering }(\gamma \mathrm{d})\end{array}$ & CBR \\
\cline { 2 - 8 } & Sirtu (\%) & Batu1-2 $(\%)$ & Tanah $(\%)$ & $\%$ & $\%$ & $\left(\mathrm{~g} / \mathrm{cm}^{3}\right)$ & $\%$ \\
\hline 1 & 65 & 15 & 20 & 4,16 & 8,11 & 2,042 & 55,75 \\
2 & 60 & 15 & 25 & 6,08 & 8,60 & 2,011 & 53,24 \\
3 & 55 & 15 & 30 & 8,90 & 8,84 & 2,002 & 51,23 \\
\hline
\end{tabular}

Sumber: Data Olahan (2019)

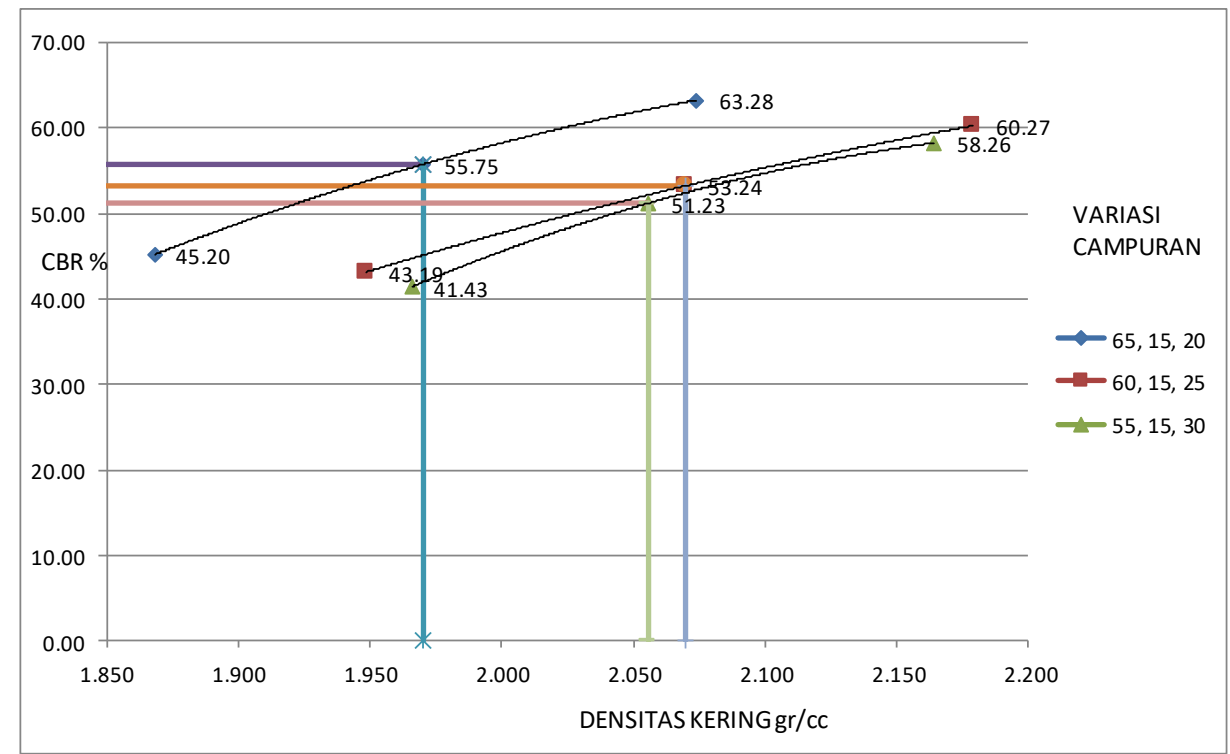

Sumber: Data Olahan (2019)

Gambar 2 Grafik CBR Desain Gabungan

Nilai $\mathrm{PI}=4,16 \%$ dengan variasi campuran agregat sirtu 65\% + Batu Pecah 1-2 15\% dan tanah 20\% memperoleh nilai $\mathrm{CBR}=55,75 \%$, nilai $\mathrm{PI}=6,08 \%$ dengan variasi campuran agregat sirtu $60 \%$ + Batu Pecah 1-2 15\% dan tanah 25\% memperoleh nilai CBR $=53,24 \%$, 
nilai $\mathrm{PI}=8,90 \%$ dengan variasi campuran agregat sirtu 55\% + Batu Pecah 1-2 15\% dan tanah $30 \%$ memperoleh nilai $\mathrm{CBR}=51,23 \%$. Berdasarkan dari hasil pengujian yang di lakukan di labolatorium di dapatkan nilai korelasi atau hubungan antara nilai PI dengan nilai CBR dari ketiga variasi dapat disimpulkan semakin tinggi nilai PI nilai CBR akan mengalami penurunan, dikarenakan sifat plastis ini hanya dibatasi $4-15 \%$ untuk lapis pondasi agregat kelas-s dan fungsi dari agregat yang bersifat plastis ini hanya sebagai pengikat.

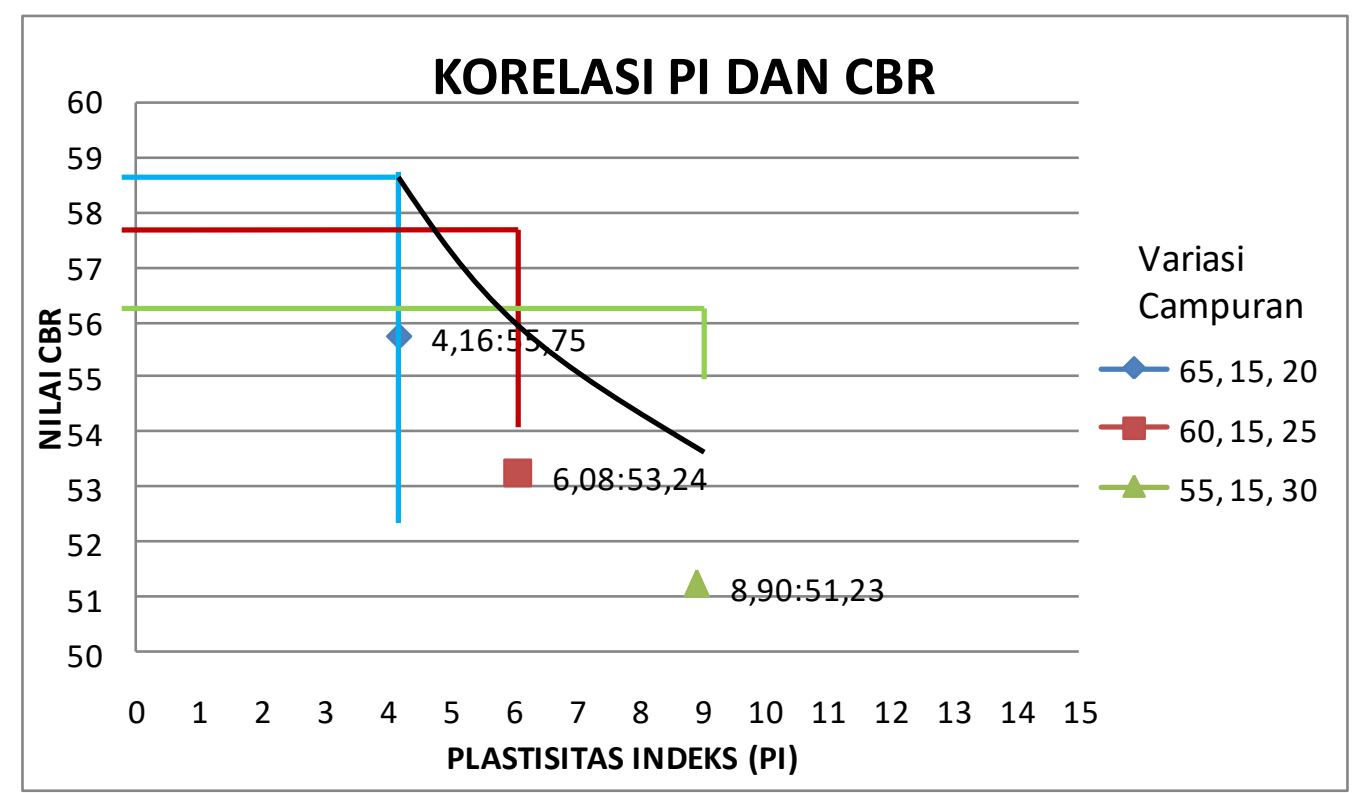

Sumber: Data Olahan (2019)

Dapat disimpulkan bahwa semakin besar penambahan tanah dan pengurangan sirtu maka semakin rendah nilai CBR yang diperoleh dengan variasi campuran 65,15,20 untuk nilai $\mathrm{PI}=4,16 \%$ mendapatkan nilai $\mathrm{CBR}=55,75 \%$ varias campuran $60,15,25$ untuk nilai $\mathrm{PI}=6,08$ mendapatkan nilai $\mathrm{CBR}=53,24 \%$, dan variasi campuran 55, 15,30 untuk nilai $\mathrm{PI}=$ $8,90 \%$ mendapatkan nilai $\mathrm{CBR}=51,23 \%$. Dari grafik 4.3 membuktikan bahwa pengaruh maerial plastis sangat menentukan nilai CBR.

\section{Ringkasan Sirtu $65 \%$, Batu Pecah 1-2 15\% dan Tanah $20 \%$}

Tabel 8 Ringkasan Sirtu $65 \%$, Batu Pecah 1-2 15\% dan Tanah 20\%

\begin{tabular}{|c|c|c|c|c|c|}
\hline NO & \multicolumn{2}{|c|}{ JENIS PENGUJIAN } & $\begin{array}{l}\text { UKURAN } \\
\text { SARINGAN }\end{array}$ & $\begin{array}{l}\text { HASIL } \\
\text { TES } \\
\text { GAB }\end{array}$ & $\begin{array}{c}\text { SPESIFIKASI } \\
\text { LAPIS PONDASI } \\
\text { KELAS S } \\
\text { BINA MARGA } \\
\text { TAHUN 2010 REVISI } 3 \\
\end{array}$ \\
\hline \multirow{8}{*}{1} & \multirow{8}{*}{\multicolumn{2}{|c|}{$\begin{array}{l}\text { ANALISA SARINGAN } \\
(\% \text { Lolos Saringan ) }\end{array}$}} & 2" & & \\
\hline & & & $11 / 2 "$ & 100.00 & 100 \\
\hline & & & 1" & 83.69 & $77-89$ \\
\hline & & & $3 / 8$ & 49.95 & $41-66$ \\
\hline & & & \# 4 & 40.07 & $26-54$ \\
\hline & & & $\# 10$ & 33.32 & $15-42$ \\
\hline & & & \# 40 & 17.75 & $7^{\prime}-26$ \\
\hline & & & \# 200 & 10.38 & $4^{\prime}-16$ \\
\hline \multirow{3}{*}{2} & \multirow{3}{*}{ ATTERBERG LIMITS } & \multicolumn{2}{|c|}{ BATAS CAIR ( LL ) \% } & 27.71 & $0-35$ \\
\hline & & \multicolumn{2}{|c|}{ BATAS PLASTIS ( PL ) \% } & 23.55 & - \\
\hline & & \multicolumn{2}{|c|}{ INDEKS PLASTISTTAS ( PI) \% } & 4.16 & $4-15$ \\
\hline 3 & \multicolumn{3}{|c|}{ KADAR AIR OPTIMUM / OMC (\%) } & 8.11 & - \\
\hline 4 & \multicolumn{3}{|c|}{ BERAT ISI KERING, yd (t/m3) } & 2.042 & - \\
\hline \multirow{2}{*}{5} & \multirow{2}{*}{ C B R (\%) } & \multirow{2}{*}{\multicolumn{2}{|c|}{$\frac{100 \% \text { MDD }}{95 \% \text { MDD }}$}} & 63.28 & - \\
\hline & & & & 55.75 & Min. 50 \\
\hline 6 & \multicolumn{3}{|l|}{ BERAT JENIS / Gs } & 2.477 & \\
\hline
\end{tabular}

Sumber: Data Olahan (2019) 

Kelas-S

Dapat di simpulkan dari tabel 8 ringkasan sirtu $65 \%$, batu pecah 1-2 15\% dan tanah $20 \%$ untuk analisa saringan \% lolos masuk dalam spesifikasi 2010 revisi 3 dari mulai lolos saringan 11/2" sampai 200, untuk pengujian atterberg limit batas cair di dapat 27,71\% masuk dalam batas yang di izinkan menurut spek $0-35 \%$, batas plastis $23,55 \%$ dan indek plastisitas didapat $4,16 \%$ dan syarat yang diizinkan $4-15 \%$, kadar aiar optimum didapat $8,11 \%$ dari pengujian pemadatan, berat isi kering 2,042\% untuk nilai CBR yang di dapat di 95\% MDD nilai CBR 55,75\% syarat yang diizinkan min 50\% berat jenis di dapat 2,477 gs. Memenuhi spesifikasi umum binamarga 2010 revisi 3.

\section{Ringkasan Sirtu $60 \%$, Batu Pecah 1-2 15\% dan Tanah 25\%}

Tabel 9 Ringkasan Sirtu $60 \%$, Batu Pecah 1-2 15\% dan Tanah 25\%

\begin{tabular}{|c|c|c|c|c|c|}
\hline NO & \multicolumn{2}{|c|}{ JENIS PENGUJIAN } & $\begin{array}{l}\text { UKURAN } \\
\text { SARINGAN }\end{array}$ & $\begin{array}{l}\text { HASIL } \\
\text { TES } \\
\text { GAB }\end{array}$ & $\begin{array}{c}\text { SPESIFIKASI } \\
\text { LAPIS PONDASI } \\
\text { KELAS S } \\
\text { BINA MARGA } \\
\text { TAHUN } 2010 \text { REVISI } 3\end{array}$ \\
\hline \multirow{8}{*}{1} & \multirow{8}{*}{\multicolumn{2}{|c|}{$\begin{array}{l}\text { ANALISA SARINGAN } \\
\text { ( } \% \text { Lolos Saringan ) }\end{array}$}} & $2 "$ & & \\
\hline & & & $11 / 2^{\prime \prime}$ & 100.00 & 100 \\
\hline & & & $1 "$ & 84.95 & $77-89$ \\
\hline & & & $3 / 8$ & 52.81 & $41-66$ \\
\hline & & & $\# 4$ & 43.44 & $26-54$ \\
\hline & & & \# 10 & 36.73 & $15-42$ \\
\hline & & & \# 40 & 20.00 & $7^{\prime}-26$ \\
\hline & & & $\# 200$ & 11.72 & $4^{\prime}-16$ \\
\hline \multirow{3}{*}{2} & \multirow{3}{*}{ ATTERBERG LIMITS } & \multicolumn{2}{|c|}{ BATAS CAIR ( LL ) \% } & 34.36 & $0-35$ \\
\hline & & \multicolumn{2}{|c|}{ BATAS PLASTIS ( PL ) \% } & 28.28 & - \\
\hline & & \multicolumn{2}{|c|}{ INDEKS PLASTISITAS ( PI ) \% } & 6.08 & 4-15 \\
\hline 3 & \multicolumn{3}{|c|}{ KADAR AIR OPTIMUM / OMC (\%) } & 8.60 & - \\
\hline 4 & \multicolumn{3}{|c|}{ BERAT ISI KERING, yd (t/m3) } & 2.011 & - \\
\hline \multirow{2}{*}{5} & \multirow{2}{*}{ C B R (\%) } & \multicolumn{2}{|c|}{$100 \%$ MDD } & 60.27 & - \\
\hline & & \multicolumn{2}{|c|}{$95 \%$ MDD } & 53.24 & Min. 50 \\
\hline 6 & \multicolumn{3}{|l|}{ BERAT JENIS / Gs } & 2.465 & - \\
\hline
\end{tabular}

Sumber: Data Olahan (2019)

Dapat di simpulkan dari tabel 9 ringkasan sirtu $60 \%$, batu pecah 1-2 15\% dan tanah $25 \%$ untuk analisa saringan \% lolos masuk dalam spesifikasi 2010 revisi 3 dari mulai lolos saringan 11/2" sampai 200, untuk pengujian atterberg limit batas cair di dapat 34,36\% masuk dalam batas yang di izinkan menurut spek $0-35 \%$, batas plastis $23,55 \%$ dan indek plastisitas didapat $6,08 \%$ dan syarat yang diizinkan $4-15 \%$, kadar aiar optimum didapat $8,11 \%$ dari pengujian pemadatan, berat isi kering 2,011\% untuk nilai CBR yang di dapat di $95 \%$ MDD nilai CBR 53,24\% syarat yang diizinkan min $50 \%$ berat jenis di dapat 2,477. Memenuhi spesifikasi umum binamarga 2010 revisi 3. 


\section{Ringkasan Sirtu $55 \%$, Batu Pecah 1-2 $15 \%$ dan Tanah 30\%}

Tabel 10 Ringkasan Sirtu $55 \%$, Batu Pecah 1-2 15\% dan Tanah 30\%

\begin{tabular}{|c|c|c|c|c|c|}
\hline $\mathrm{NO}$ & \multicolumn{2}{|c|}{ JENIS PENGUJIAN } & $\begin{array}{c}\text { UKURAN } \\
\text { SARINGAN }\end{array}$ & $\begin{array}{l}\text { HASIL } \\
\text { TES } \\
\text { GAB }\end{array}$ & $\begin{array}{c}\text { SPESIFIKASI } \\
\text { LAPIS PONDASI } \\
\text { KELAS S } \\
\text { BINA MARGA } \\
\text { TAHUN } 2010 \text { REVISI } 3\end{array}$ \\
\hline \multirow{8}{*}{1} & \multirow{8}{*}{\multicolumn{2}{|c|}{$\begin{array}{l}\text { ANALISA SARINGAN } \\
\text { ( } \% \text { Lolos Saringan ) }\end{array}$}} & 2" & & \\
\hline & & & $11 / 2 "$ & 100.00 & 100 \\
\hline & & & 1" & 86.20 & $77-89$ \\
\hline & & & $3 / 8$ & 55.67 & $41-66$ \\
\hline & & & \# 4 & 46.82 & $26-54$ \\
\hline & & & $\# 10$ & 40.14 & $15-42$ \\
\hline & & & \# 40 & 22.25 & $7^{\prime}-26$ \\
\hline & & & $\# 200$ & 13.07 & $4^{\prime}-16$ \\
\hline \multirow{3}{*}{2} & \multirow{3}{*}{ ATTERBERG LIMITS } & \multicolumn{2}{|c|}{ BATAS CAIR ( LL ) \% } & 35.78 & $0-35$ \\
\hline & & \multicolumn{2}{|c|}{ BATAS PLASTIS ( PL ) \% } & 26.88 & - \\
\hline & & \multicolumn{2}{|c|}{ INDEKS PLASTISTAS ( PI ) \% } & 8.90 & 4-15 \\
\hline 3 & \multicolumn{3}{|c|}{ KADAR AIR OPTIMUM / OMC (\%) } & 8.84 & - \\
\hline 4 & \multicolumn{3}{|c|}{ BERAT ISI KERING, yd (t/m3) } & 2.002 & - \\
\hline \multirow{2}{*}{5} & \multirow{2}{*}{ C B R $(\%)$} & \multicolumn{2}{|c|}{$100 \%$ MDD } & 58.26 & - \\
\hline & & \multicolumn{2}{|c|}{$95 \%$ MDD } & 51.23 & Min. 50 \\
\hline 6 & \multicolumn{3}{|l|}{ BERAT JENIS / Gs } & 2.453 & - \\
\hline
\end{tabular}

Sumber: Data Olahan (2019)

Dapat di simpulkan dari tabel 10 ringkasan sirtu $55 \%$, batu pecah 1-2 15\% dan tanah $30 \%$ untuk analisa saringan \% lolos masuk dalam spesifikasi 2010 revisi 3 dari mulai lolos saringan 11/2" sampai 200, untuk pengujian atterberg limit batas cair di dapat 35,78\% masuk dalam batas yang di izinkan menurut spek $0-35 \%$, batas plastis $26,88 \%$ dan indek plastisitas didapat $8,90 \%$ dan syarat yang diizinkan $4-15 \%$, kadar aiar optimum didapat 8,84\% dari pengujian pemadatan, berat isi kering 2,002\% untuk nilai CBR yang di dapat di $95 \%$ MDD nilai CBR 51,23\% syarat yang diizinkan min 50\% berat jenis di dapat 2,453 gs. Memenuhi spesifikasi umum binamarga 2010 revisi 3.

\section{SIMPULAN}

Dari hasil Penelitian yang dilakukan maka dapat disimpulkan bahwa sirtu dan Batu Pecah 1-2 tidak memiliki Indeks plastisitas dan untuk tanah memiliki indeks plastisitas sebesar PI=14,50\%. Nilai $\mathbf{P I}=4,16 \%$ mendapatkan nilai $\mathbf{C B R}=55,75 \%$, Nilai $\mathbf{P I}=6,08 \%$ mendapatkan nilai $\mathbf{C B R}=53,24 \%$,Nilai $\mathbf{P I}=8,60 \%$ mendapatkan nilai $\mathbf{C B R}=51,23 \%$

Untuk campuran sirtu 65\% + Batu Pecah 1-2, $15 \%+$ tanah $20 \%$ di dapat PI= 4,16 $\%$, dan nilai $\mathbf{C B R}=55,75 \%$, Wopt $8,11 \%$, $\boldsymbol{\gamma d} \mathbf{~} \mathbf{m a x}=2,042 \mathrm{gr} / \mathrm{cm}^{3}$ memenuhi Spesifikasi Umum Binamarga 2010 revisi 3 yaitu CBR minimal $50 \%$.

Untuk campuran Sirtu 60\% + Batu Pecah 1-2, $15 \%$ + Tanah $25 \%$ di dapat PI=6,08

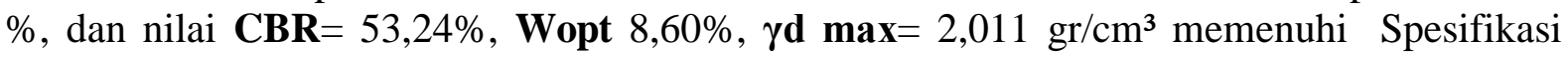
Umum Binamarga 2010 revisi 3 yaitu CBR minimal 50\%.

Untuk campuran Sirtu 55\% + Batu Pecah 1-2, $15 \%$ + Tanah 30\% di dapat PI=8,90 $\%$, dan nilai $\mathbf{C B R}=51,23 \%$, Wopt $8,84 \%$, $\boldsymbol{\gamma d} \mathbf{d} \mathbf{m a x}=2,002 \mathrm{gr} / \mathrm{cm}^{3}$ memenuhi Spesifikasi Umum Binamarga 2010 revisi 3 yaitu CBR minimal 50\%. 
Adanya peningkatan nilai index plastisitas dari campuran material yang digunakan untuk lapis pondasi sangat mempengaruhi nilai CBR.Terlihat dari meningkatnya nilai PI membuat nilai CBR rendah.

\section{DAFTAR PUSTAKA}

Bowles, J. E. 1989 Sifat-sifatFisis dan Geoteknis Tanah (Mekanika Tanah) Edisi Kedua, Penerbit Erlangga, Jakarta

Braja M. Das, 1995, Mekanika Tanah, Prinsip prinsip Rekayasa Geoteknik, jilid 1 Erlangga,Jakarta,

Edisi 2010 (Revisi 3). Republik Indonesia Kementrian Pekerjaan Umum Direktorat Jendral Bina Marga Spesifikasi Umum untuk Dokumen Pelelangan Nasional Penyediaan Pekerjaan Konstruksi (Pemborongan) Untuk Kontrak Harga Satuan.

Geoteknik dan Mekanika Tanah 1987.

Hardiyatmo Hary Christady. 2012 Mekanika Tanah 1 Edisi Keenam, Penerbit Gajah Mada University Press, Yogyakarta

Intan Sari Okatiara. 2017. Stabilisasi Tanah Lempung Menggunakan Kerikil Untuk meningkatkan Daya Dukung (CBR) di Labolatorium Sebagai Bahan

JurnalAdelina A.R Runtuwene dkk (Pengaruh Variasi Nilai Index Plastisitas Dari Agregat Halus Terhadap Daya Dukung Lapis Pondasi Agregat Kelas-A)

L.D.Wesley.1977. Mekanika Tanah, cetakan VI, Badan Penerbit Pekerjaan Umum

Marcitra Kurniati. 2017. Penambahan Pasir Untuk Meningkatkan Nilai CBR Tanah Lempung Ekspansif. Tugas Akhir Program S1 Teknik Sipil. Universitas Batanghari. Jambi

Modul Pelatihan Bidang Geoteknik Departemen Pekerjaan Umum (1988)

Sukirman S. 1992. Perkerasan Lentur Jalan Raya, Penerbit Nova Bandung

Sukirman S. 2010. Perencanaan Tebal Struktur Perkerasan Lentur, Penerbit Nova Bandung

Soedarmo G. Djatmiko. 1993. Mekanika Tanah 1, Penerbit Kanisius, Malang

Suyono Sasrodarsono,1984, Mekaniaka Tanah dan Teknik Pondasi, PT Pradnya Pramita, Jakarta,

Spesifikasi Umum Bina Marga (2010). Perkerasan Berbutir Revisi 3 